\title{
CONVERSION OF POLYSTYRENE PLASTIC WASTE AND USED PALM OIL CO-REACTANT INTO LIQUID FUEL USING AL-MCM-41/CERAMICS CATALYST
}

\author{
H. Juwono' ${ }^{1}$, W. Trisunaryanti ${ }^{2}$, L. Efiyanti ${ }^{3}$, S.l Bahri ${ }^{4}$, K. Amri ${ }^{5}$, A. Assari ${ }^{1}$, \\ S. Suprapto ${ }^{1}$ and Y. L. Ni'mah ${ }^{1, \varpi}$ \\ ${ }^{1}$ Chemistry Department, Faculty of Science and Analytica Data, Institut Teknologi Sepuluh \\ Nopember, 60111, Surabaya, Indonesia. \\ ${ }^{2}$ Chemistry Department, Faculty of Mathematics and Natural Sciences, Universitas Gajah Mada, \\ 55281, Yogyakarta, Indonesia. \\ ${ }^{3}$ Pusat Penelitian Dan Pengembangan Hasil Hutan, Badan Litbang Dan Inovasi, KLHK, \\ Bogor, Indonesia. \\ ${ }^{4}$ Chemical Engineering Department, Universitas Riau Kampus Binawidya, \\ Pekanbaru, Indonesia. \\ ${ }^{5}$ Balai Teknologi Bahan Bakar dan Rekayasa Desain Badan Pengkajian dan Penerapan \\ Teknologi, 15314, Serpong, Tangerang Selatan, Indonesia. \\ ${ }^{\square}$ Corresponding Author: yatimnikmah@gmail.com
}

\begin{abstract}
The conversion of polypropylene plastic waste and used palm oil co-reactant into liquid fuel has been successfully carried out. The conversion was carried out by catalytic pyrolysis method. In this study, polystyrene (PS) plastic waste and polystyrene/used palm oil biodiesel (PS/BMJ) were used as raw materials to produce liquid fuels through the catalytic pyrolysis process. The catalyst used in this study was Al-MCM-41: Ceramics (7:3). The results showed that liquid fuel has high gasoline $\left(\mathrm{C}_{7}-\mathrm{C}_{12}\right)$ fraction. The liquid fuels that blended with $750 \mathrm{~mL}$ premium and $18.4 \mathrm{~mL}$ MTBE has good thermal efficiency and calorific value.

Keywords: Liquid Fuel, Catalytic Pyrolysis, Polystyrene, Plastic Waste, Used Cooking Oil

RASĀYYAN J. Chem., Vol. 14, No.2, 2021

\section{INTRODUCTION}

The pyrolysis of plastics and biomass co-reactant has been widely studied because of the liquid fuel quality that produced..$^{1-3}$ One biomass that can be used to improve the quality of plastic liquid fuel produced by pyrolysis was used palm oil. Pretreatment of biomass before pyrolysis was one factor that contributes to the quality of liquid fuels. ${ }^{4,5}$ One of the pretreatment methods was transesterification reaction to convert used palm oil into methyl ester or biodiesel. Biodiesel from used palm oil can be applied as a source of hydrocarbons to makes pyrolysis products that have characteristics similar to gasoline. ${ }^{6}$

Solid catalysts such as zeolite ZSM-5, Y-zeolite, and MCM- $419^{7,8}$ have been widely studied for the catalytic pyrolysis process. From several studies, MCM-41 was a promising catalyst compared to zeolite microstructure. It was because microporous zeolite restricts high molecular weight hydrocarbons that derived from pyrolysis of plastics to be reacted due to steric hindrances or diffusion constraints. ${ }^{9}$ MCM41 is the catalyst that has several active sides including acid and uniform mesoporous hexagonal shape with a large surface area. The acid site can be improved by the incorporation of Al metal into MCM-41 of form Al-MCM-41. ${ }^{10}$ Previous studies ${ }^{11}$ have shown that Al-MCM-41 or composite catalysts which comprised Al-MCM-41 with ZSM-5 have good activity in the catalytic cracking of plastic waste to produce gasoline. Catalytic pyrolysis of HDPE waste using Al-MCM-41: ZSM-5 produce high aromatic oil product (95.85 $\mathrm{wt} \%$ of oil) that contain $97.72 \mathrm{wt} \%$ of gasoline hydrocarbon fraction.
\end{abstract}


RASĀYAN J. Chem.

Vol. 14 | No. 2 |1049-1056| April - June | 2021

Juwono et al ${ }^{12}$ has produced biofuels from polypropylene plastic waste using used palm oil as a co-reactant. The biofuel obtained has a gasoline $\left(\mathrm{C}_{7}-\mathrm{C}_{12}\right)$ fraction of $93.92 \%$. The characteristics of liquid fuels were in accordance with fuel-oil quality SNI 06-3506-1994. However, liquid fuels that were obtained did not have aromatic compounds. Aromatic compounds on fuel were needed as anti-knocking. Gasoline must have branched alkane, aromatic, or alicyclic other than straight-chain alkanes to comply with application requirements. Thus, plastics that have aromatic moieties were required as alternative raw materials. One of the plastics that have aromatic moieties is polystyrene (PS).

Polystyrene (PS) plastic is mostly applied as packaging materials. Polystyrene is a polymer of styrene monomer with benzene as an aromatic group. Aromatic group existence in PS waste poses an environmental issue when decomposed. On the other hand, the PS has a calorific value of $41.4 \mathrm{MJ} / \mathrm{kg}$ so that it can be processed into conventional fossil fuel substitutes. ${ }^{13}$

In this study, the conversion of PS plastic and used cooking oil co-reactant was carried out using catalytic pyrolysis method with Al metal modified MCM-41 catalyst and ceramic supporting solids. The conversion results were analyzed using Gas Chromatography-Mass Spectrometry (GC-MS) and physical characteristics include density, flash point, calorific value, octane number and performance tests on the generator engine. The results are compared with SNI 06-3506-1994 and HIBER11Z Hibernia Petroleum Canada 2016 regarding the quality of gasoline fuel. ${ }^{9}$

\section{EXPERIMENTAL}

\section{Material and Methods}

The materials used in this research were used palm oil, polystyrene (PS) plastic waste, methyl tertiary butyl ether (MTBE), catalyst Al-MCM-41, ceramics, sodium hydroxide $(\mathrm{NaOH})$, methanol p.a. from Merck, Nitrogen (UHP)

\section{Preparation of Catalyst Al-MCM-41}

Al-MCM-41 catalysts were synthesized by the hydrothermal method. ${ }^{10}$ The synthesized Al-MCM-41 catalyst was activated by heating at $110^{\circ} \mathrm{C}$ to remove water in the catalyst pores and stored in a desiccator. The ceramic material was obtained from spark plug ceramic and ground to obtain a ceramic powder with a mesh of 100 . The catalysts that were synthesized were activated at $80^{\circ} \mathrm{C}$ and mixed with ceramic powder in Al-MCM-41: ceramic powders ratio of (7:3). The mixture was molded using a pellet press tool. ${ }^{9}$

\section{Characterization of Al-MCM-41}

XRD characterization was carried out at $40 \mathrm{kV}$ and $40 \mathrm{~mA}$ using $\mathrm{Cu} \mathrm{K} \alpha$ with $2 \theta$ from $10^{\circ}$ to $80^{\circ}$. The surface morphology of the catalyst was analyzed using Scanning Electron Microscope (SEM, FEI Quanta $20 \mathrm{~F}$ ). The pore size and porosity of the catalyst were determined using $\mathrm{N}_{2}$ adsorption-desorption method (Micromeritics TriStar II 3020 Automatic Physisorption Analyzer). The catalyst was vacuumed at $300^{\circ} \mathrm{C}$ for 1 hour to remove the trapped gas. The Brunauer-Emmett-Teller equation was used to calculate the surface area, $\mathrm{p} / \mathrm{po}=0.05-0.25$. Pore volume was measured using Barrett-Joyner-Halenda (BJH) method. Acidity on the catalyst was calculated from Pyridine-Adsorption Fourier Transform Infrared (Piridin-FTIR) method. The quantity of Bronsted and Lewis acid was calculated using eqns.-1 and 2 respectively. ${ }^{14}$

$$
\begin{aligned}
& C(B)=\operatorname{IMEC}(B)^{-1} \times I A(B) \times \frac{\pi R^{2}}{W} \\
& C(L)=\operatorname{IMEC}(L)^{-1} \times I A(L) \times \frac{\pi R^{2}}{W}
\end{aligned}
$$

Where $\mathrm{C}$ is the concentration ( $\mu \mathrm{mol} / \mathrm{g}$ catalyst), $\operatorname{IMEC}(\mathrm{B}, \mathrm{L})$ the integrated molar extinction coefficients $(\mathrm{cm} / \mu \mathrm{mol})$, IA $(\mathrm{B}, \mathrm{L})$ the integrated absorbance $\left(\mathrm{cm}^{-1}\right), \mathrm{R}$ the radius of catalyst disk $(\mathrm{cm})$, and $\mathrm{W}$ is the weight of disk (mg).

\section{Synthesized of Biodiesel}

The synthesis of used cooking oil biodiesel was carried out by transesterification reaction. Used cooking oil was put into the three-neck flask and heated to $50^{\circ} \mathrm{C}$ to remove the impurities. $\mathrm{NaOH} 2 \%(\mathrm{w} / \mathrm{w})$ that has been dissolved in methanol was added. The molar ratio of used cooking oil to methanol in the mixture was 1:3. The reaction was carried out for 2 hours at $50^{\circ} \mathrm{C}$ and stirred at $500 \mathrm{rpm}$. The methyl ester was separated 
from glycerol in the separating funnel after settled for 24 hours. The resulting biodiesel was then washed with demineralized water and evaporated using a rotary evaporator to remove the $\mathrm{NaOH}$ and other impurities.

\section{Synthesis of Liquid Fuels}

Polystyrene (PS) foam waste was used as feedstock in the catalytic pyrolysis process to produce liquid oil. These raw materials were collected from the disposal site in Keputih, Surabaya, Indonesia. PS foam was prepared by cutting it into small pieces $(2 \mathrm{~cm} \times 2 \mathrm{~cm})$ and pressed to reduce its dimension. The synthesis of liquid fuel was carried out in a continuous reactor. The fuel was placed in Erlenmeyer. Al-MCM-41: Ceramics (7:3) catalyst was used in PS and PS/BMJ catalytic pyrolysis. Catalytic pyrolysis of PS and PS/BMJ was carried out for 60 and 120 minutes. Cracking products were mixed with Premium RON 88 and MTBE to obtain optimum performance on the gasoline engine.

\section{Characterization of Hydrocarbon Liquid Fuel and Performance Test}

The characterization of hydrocarbon fuels that was carried out included: calorific value, Gas Chromatography-Mass Spectrometry (GC-MS), and performance test in the gasoline-based fuel engines. GC-MS was applied to determine the chemical components.

\section{Characterization of Catalyst}

\section{RESULTS AND DISCUSSION}

The effect of ceramic mixing into Al-MCM-41 catalyst on its crystallinity structure has been studied using XRD and the pattern recorded was presented in Fig.-1. WAXRD pattern of the Al-MCM-41 showed a broad peak at $2 \theta=22^{\circ}$ which confirmed the natural amorphous phase of the ordered silica. The mixing of ceramic with Al-MCM-41 produces partial destruction of the hexagonal structure as seen from the small shifting in the diffraction peak. The siliceous MCM-41 presented a pattern that correspond to the highest hexagonal order arrangement of the mesopores. ${ }^{15}$ The crystal in the field (100), (110), (200) were the characteristic angles of MCM-41 catalyst at $2 \theta=1-5^{\circ}$ as presented in Fig.-2. Moreover, several sharp peaks were observed at $2 \theta=35,0866^{\circ} ; 37,7459^{\circ}$; and $43,2584^{\circ}$ in the WAXRD of Al-MCM-41: ceramic sample which corresponds to the characteristic peak of the ceramic. Thus, it could be concluded that the incorporation of Al-MCM into ceramics was successfully carried out without a significant change in the hexagonal structure of Al-MCM-41 and the crystal structure of the ceramic.

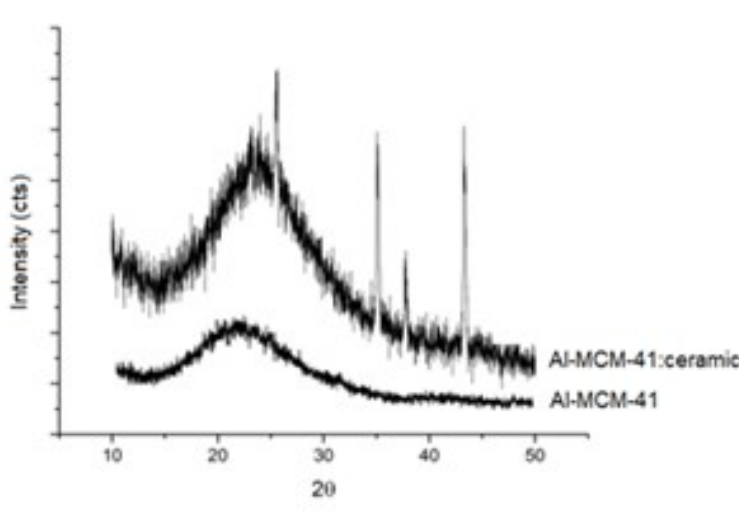

Fig.-1: Diffractogram of MCM-41 and MCM-41: Ceramics

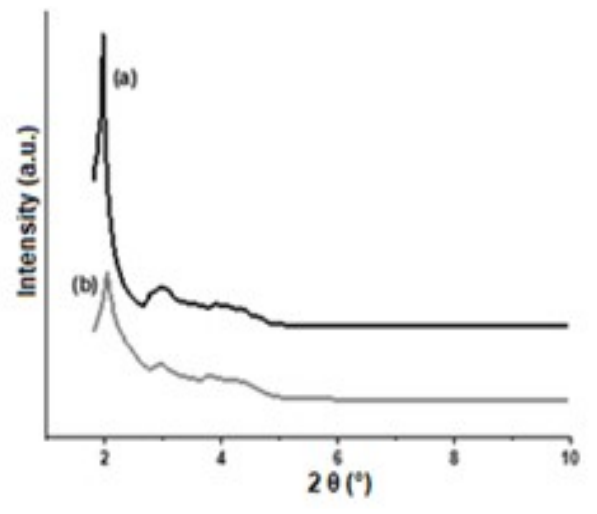

Fig.-2: SAXRD Diffractogram of (a)MCM-41 and (b)MCM-41: Ceramics

\section{$\mathbf{N}_{2}$ Adsorption-Desorption Characterization of Al-MCM-41 Catalyst: Ceramics (7:3)}

Nitrogen adsorption-desorption on the Al-MCM-41 catalyst: ceramics (7: 3 ) produce a type IV isotherm curve as shown in Fig.-3. Type IV isotherm curves are typical of MCM-41. This proves that the addition of spark plug ceramics did not change the structure of MCM-41. In addition, the incorporation of ceramic into Al-MCM-41 influenced the surface area of the catalyst. The result of BET analysis was shown in Table-1. 
RASĀYAN J. Chem.

Vol. 14 | No. 2 |1049-1056| April - June | 2021

Its showed that Al-MCM-41-ceramic exhibits a larger surface area than Al-MCM-41. The surface area increased by $14.42 \%$ after the incorporation of ceramic.

Table-1: Data on $\mathrm{N}_{2}$ Adsorption-desorption Test Results

\begin{tabular}{c|c|c|c|c}
\hline No & Catalyst & Surface Area $\left(\mathrm{m}^{2} / \mathrm{g}\right)$ & Pore Volume $(\mathrm{cc} / \mathrm{g})$ & Average Pore Radii $(\AA)$ \\
\hline 1. & Al-MCM-41 & 419.93 & 0.50 & 15.12 \\
\hline 2. & Al-MCM-41:Keramik (7:3) & 490.665 & 0.546 & 22.22 \\
\hline
\end{tabular}

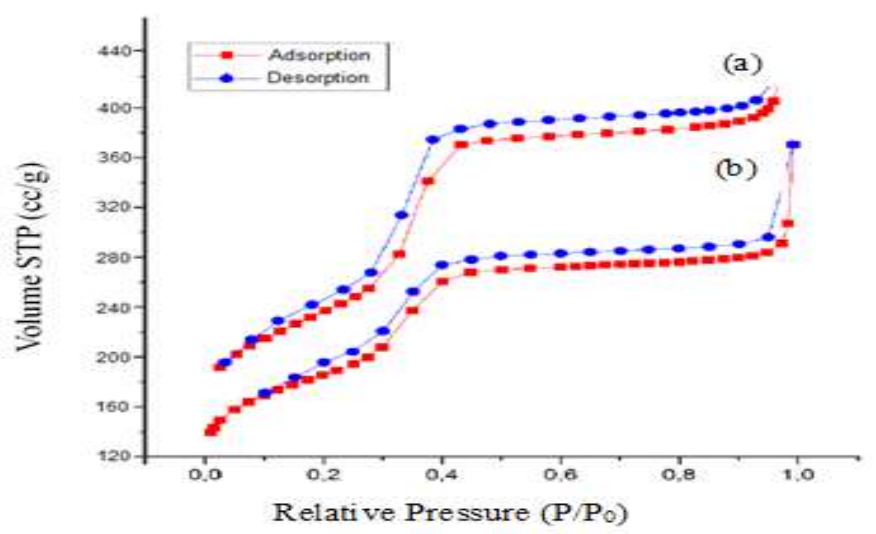

Fig.-3: (a) Reference Isotherm chart of Al-MCM-41, (b) Al-MCM-41 Isotherm Graph: Ceramics (7: 3)

\section{SEM Characterization of Al-MCM-41: Ceramics (7: 3) Catalyst}

The effect of ceramic mixing in the Al-MCM-41 on the morphology of the catalyst was presented in Fig.4. It can be seen that hexagonal structures were observed on both Al-MCM-41 and Al-MCM-41: ceramic, which was the characteristic of MCM-41 morphology. The SEM image shows that Al-MCM-41 was attached to the surface of the ceramic. Points A and B in Fig.-4(b) refer to Al-MCM-41 and ceramics parts in the catalyst respectively. In Al-MCM-41, a smooth surface of solids agglomeration with a hexagonal structure was seen. Meanwhile Al-MCM-41: Ceramics (7: 3) SEM image shows fine particles with hexagonal structures from Al-MCM-41 attached to the surface of the ceramic support materials. Hence, it can be implied that there was no structural destruction of Al-MCM-41 catalyst after ceramic mixing since no significant difference in the morphology was observed.

\section{The acidity of Al-MCM-41 Catalyst: Ceramics (7:3)}

FTIR analysis by pyridine adsorption was carried out to determine the acidity of the catalyst surface. FTIR spectrum in Fig.-5 shows the interaction between pyridine and the active site of the Al-MCM-41 catalyst: Ceramics (7: 3). Peaks at a wavenumber of $1533-1558 \mathrm{~cm}^{-1}$ indicated the active side of Bronsted Acid in the amount of $0.0344 \mathrm{mmol} / \mathrm{g}$. Peaks at wavenumbers of $1431-1460 \mathrm{~cm}^{-1}$ indicated the active side of Lewis Acid in the amount of $0.0311 \mathrm{mmol} / \mathrm{g}$.

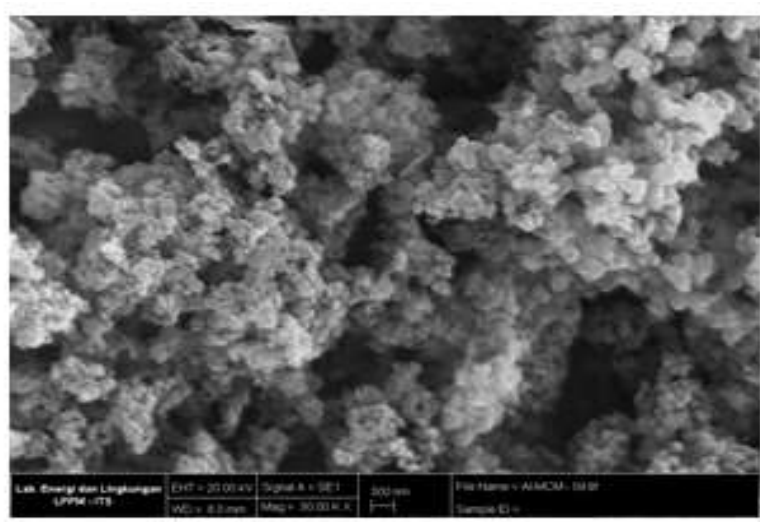

(a)

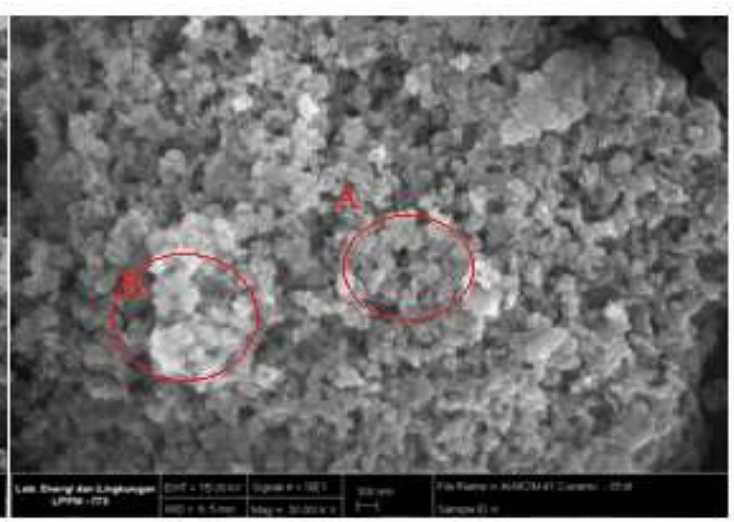

(b)

Fig.-4: SEM Images of (a) Al-MCM-41, (b) Al-MCM-41: Ceramics (7: 3) 1052 
RASĀYAN J. Chem.

Vol. 14 | No. 2 |1049-1056| April - June | 2021

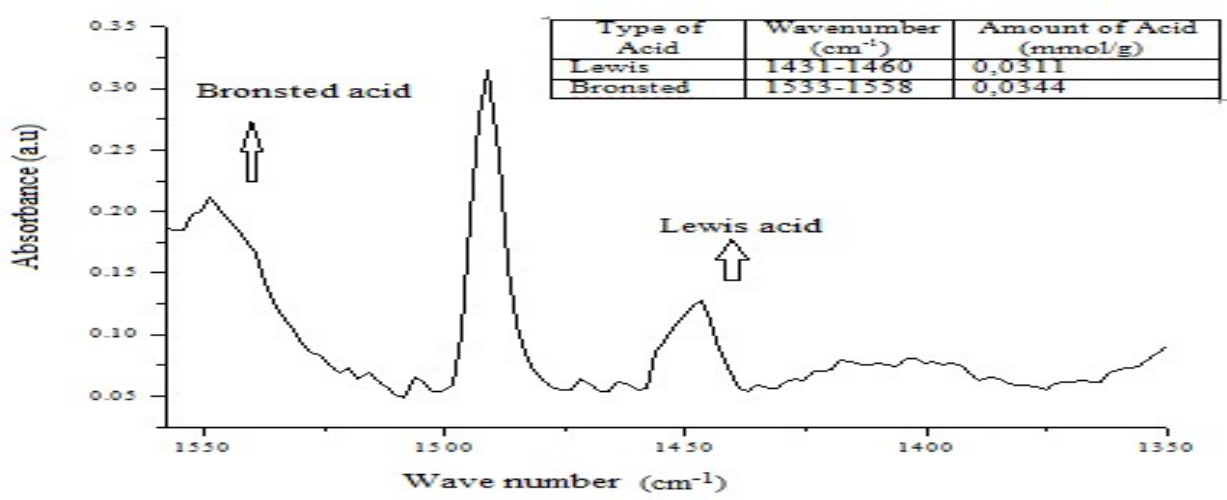

Fig.-5: FTIR Spectra of Pyridine-Al-MCM-41: Ceramics (7: 3) Catalyst

\section{Hydrocarbon Fraction of Liquid Fuels Analysis}

GC-MS chromatogram of the PS/Kat120 catalytic cracking product was presented in Fig.-6. GC-MS chromatograms showed that the chemical compounds in PS/Kat120 products were toluene $1.52 \%$, ethylbenzene $5.27 \%$, styrene $73.38 \%$, 2-phenylpropane $2.34 \%$, and $\alpha$-methyl styrene $17.36 \%$. Previous research ${ }^{16}$ concluded that PS pyrolysis products were mainly in the form of aromatic hydrocarbons. The high yield of aromatic compounds came from the degradation of PS aromatic fragments. ${ }^{17}$

GC-MS chromatograms of PS/BMJ/Kat120 catalytic cracking product were shown in Fig.-7. It shows that the addition of used cooking oil biodiesel alters the chemical compounds in the catalytic pyrolysis products. It was seen that the components in the product were more diverse with the presence of methyl ester compound because of the addition of used cooking oil biodiesel as co-reactant. These methyl ester compounds resulted from the cracking of methyl ester fragments from used cooking oil biodiesel. The chromatogram exhibit a sharp peak with high intensity of methyl dodecanoate as the second major product besides the styrene component.

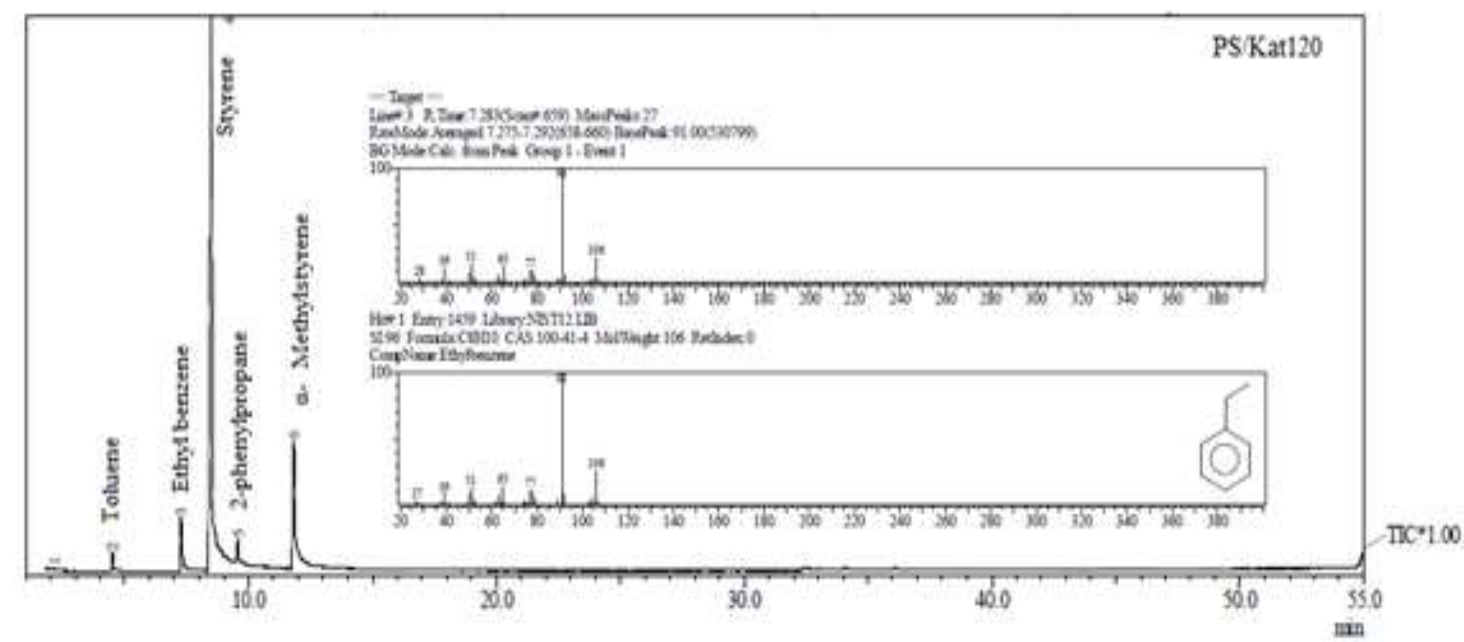

Fig.-6: GC-MS Chromatogram of PS/Kat120

In addition, GC-MS analysis shows that the catalytic pyrolysis process not only produces liquid fuel in gasoline fraction $\left(\mathrm{C}_{7}-\mathrm{C}_{12}\right)$ but also short-chain hydrocarbon fraction $\left(<\mathrm{C}_{7}\right)$ and long hydrocarbons fraction $\left(>\mathrm{C} \neg_{12}\right)$. The hydrocarbon fraction obtained from the catalytic pyrolysis process of polystyrene plastic waste with and without the addition of used cooking oil biodiesel can be seen in Fig.-8. It can be depicted from Fig. -7 that PS/Kat120 has a higher $\mathrm{C}_{7}-\mathrm{C}_{12}$ hydrocarbon fraction than PS/BMJ/Kat120. Meanwhile, the addition of waste cooking oil biodiesel showed a synergetic effect to reduce the amount of gasoline fraction $\left(\mathrm{C}_{7}-\mathrm{C}_{12}\right)$ products and increase long hydrocarbons fraction $(>\mathrm{C} \neg 12)$ products. 
RASĀYAN J. Chem.

Vol. 14 | No. 2 |1049-1056| April - June | 2021

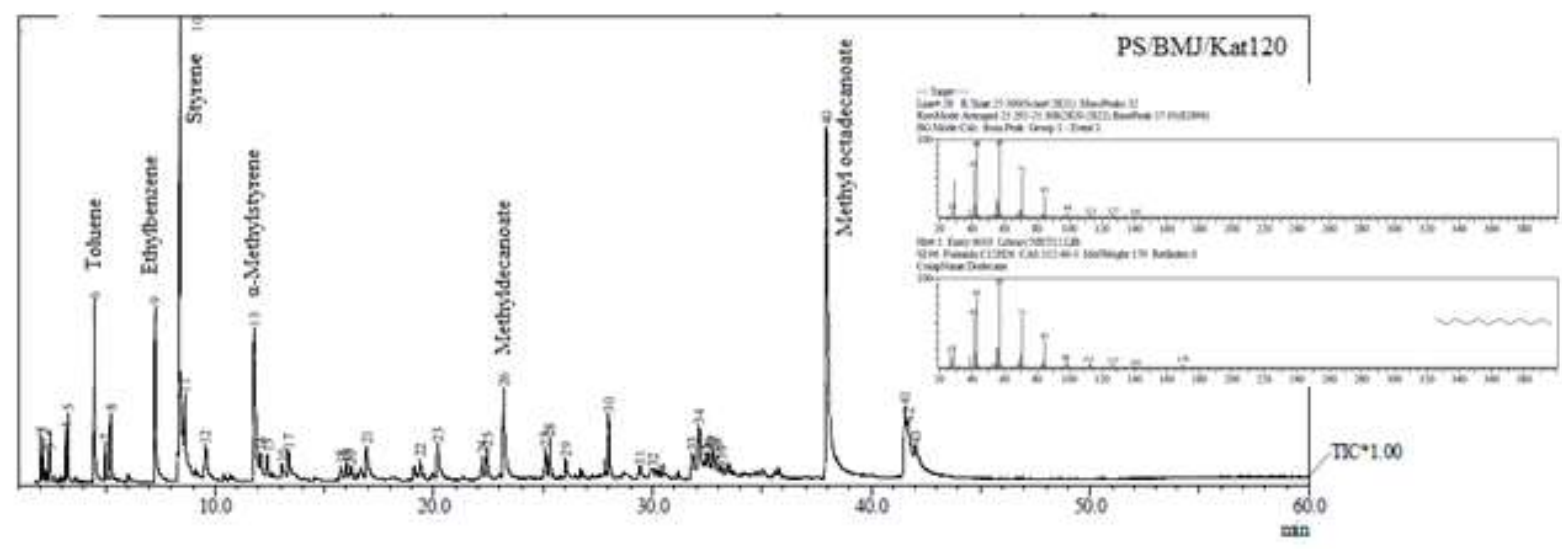

Fig.-7: GC-MS Chromatogram of PS/BMJ/Kat120

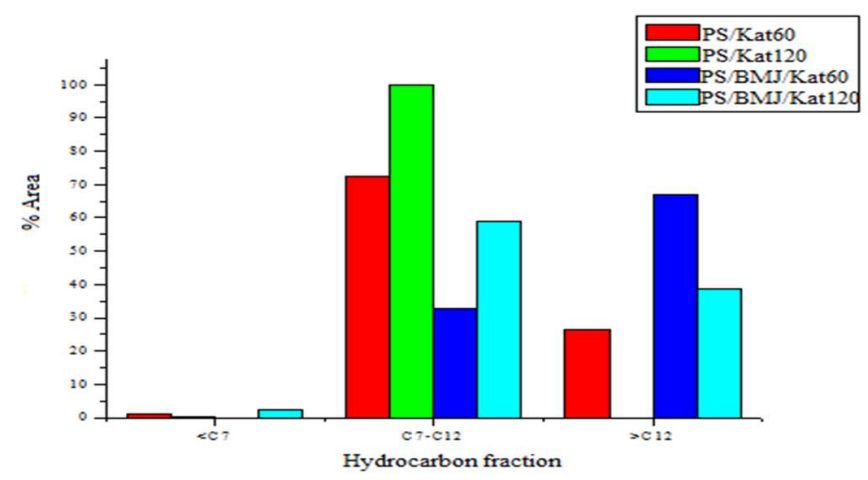

Fig.-8: Composition of Hydrocarbon Fractions

\section{Pyrolysis Reaction Mechanism}

Based on previous research ${ }^{10}$, the thermal degradation mechanism of polystyrene at high temperatures produces end-chain radicals from the breaking of the main chain followed by de-polymerization. Styrene monomers were the main compounds formed from the pyrolysis process that formed by breaking of the $\beta$ of the C-C PS bond in the main chain. ${ }^{18}$

The most commonly formed styrene derivatives in pyrolysis products are $\alpha$-methyl styrene. $\alpha$-methyl styrene that formed from the reaction between styrene monomers and methyl radicals. ${ }^{19}$ Most random cracking mechanisms produce styrene derivates. The final chain-breaking mechanism produces $\mathrm{H}_{2}$ and free radicals which are converted into aliphatic hydrocarbons through hydrogen transfer reactions..$^{20}$ Based on the composition of liquid hydrocarbon products obtained from GC-MS data, it can be inferred that the reaction mechanism of the pyrolysis process in this study is following the proposed mechanism from the previous study. ${ }^{21}$

\section{Calorific Value}

The calorific value of liquid fuel PS/BMJ/Kat was higher than the PS/Kat, as shown in Fig.-9. The Hydrocarbon composition in the pyrolysis product influenced its calorific value. CPS/BMJ/Kat 3 has the highest calorific value compared to other samples, which was $19.226 \mathrm{Kcal} / \mathrm{kg}$. The sample complies with the Hibernia Petroleum HIBER11Z standard which has a minimum calorific value of $10.347 \mathrm{Kkal} / \mathrm{kg} .{ }^{22}$

\section{Thermal Efficiency}

The thermal efficiency of liquid fuels increases as load (watts) in gasoline generator sets increased. The standard thermal efficiency (Premium + MTBE) at 1938 watts was $25.55 \%$. The liquid fuel that was synthesized in this research, at the same loading, has higher thermal efficiency which was $26.47 \%$ (Fig.10). The increase in thermal efficiency in CPS/Kat that was obtained was due to the presence of short 
RASĀYAN J. Chem.

Vol. 14 | No. 2 |1049-1056| April - June | 2021

hydrocarbon fraction $\left(\mathrm{C}_{7}-\mathrm{C}_{12}\right)$ or gasoline hydrocarbon fraction in PS/Kat product. Thermal efficiency is also influenced by the viscosity, density, and calorific value of the liquid fuels. ${ }^{1,23,24}$

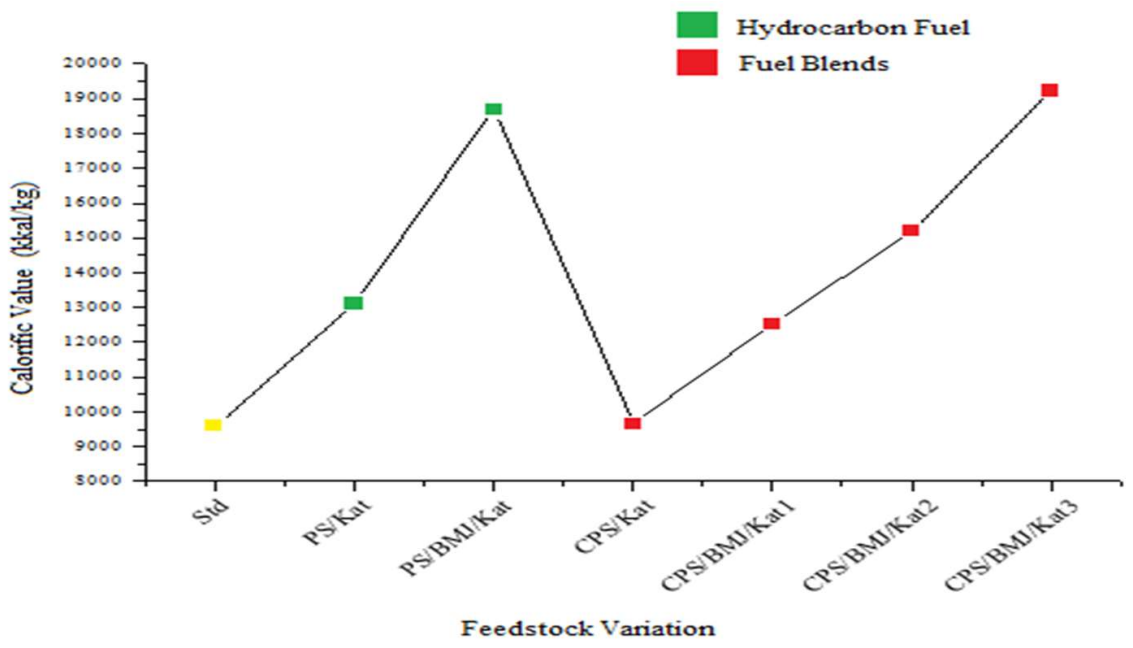

Fig.-9: The Calorific Value of Liquid Fuel

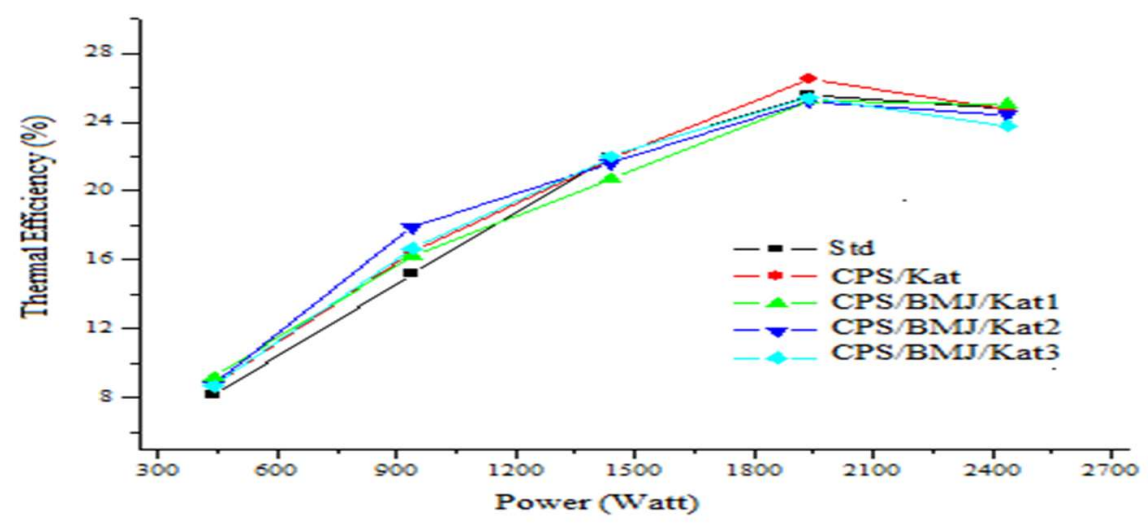

Fig.-10: Thermal Efficiency of a Mixture of Liquid Fuels

\section{CONCLUSION}

The synthesis of liquid fuels from polystyrene plastic waste and used cooking biodiesel co-reactant by catalytic pyrolysis method using Al-MCM-41: Ceramics (7:3) catalyst have been successfully carried out. The results show that the gasoline $\left(\mathrm{C}_{7}-\mathrm{C}_{12}\right)$ fraction was produced by pyrolysis using PS/Kat 120 . The $\mathrm{CPS} /$ Kat liquid fuel mixture has the highest thermal efficiency. The resulting liquid fuel both from catalytic pyrolysis of PS/Kat120 and PS/BMJ/Kat120 comply with SNI 06-3506-1994 Indonesian National Standard and HIBER11Z Hibernia Petroleum Canada 2016 regarding the quality of gasoline fuel.

\section{ACKNOWLEDGEMENT}

This research was financially supported by The Ministry of Research, Technology and Education under the scheme of KRUPT 2019 (Contract number: 1968/UN1.DITLIT/DIT-LIT/LT/2019)

\section{REFERENCES}

1. Ü. Ağbulut and H. Bakir, Düzce Üniversitesi Bilim ve Teknoloji Dergisi, 7,25(2019), DOI:10.29130/dubited.457914

2. Ü. Ağbulut d , S. Sarıdemir, and S. Albayrak, Journal of the Brazilian Society of Mechanical Sciences and Engineering, 41, 389(2019), DOI: 10.1007/s40430-019-1891-8

3. T. R. Carlson, T. P. Vispute, and G.W. Huber, Chemistry Sustainability Energi Materials, 1, 397(2008), DOI:10.1002/cssc. 200800018 
RASĀYAN J. Chem.

Vol. 14 | No. 2 |1049-1056| April - June | 2021

4. E. G. Fuentes-Ordóñez, J.A. Salbidegoitia, J.L. Ayastuy, M.A. Gutiérrez-Ortiz, M.P. González-Marcos, and J.R. González-Velasco, Catalysis Today, 227, 163(2014), DOI:10.1016/j.cattod.2013.09.004

5. M. S. Abbas-Abadi, M. N. Haghighi, H. Yeganeh, and A. G. McDonald, Journal of Analytical and Applied Pyrolysis, 109, 272(2014), DOI:10.1016/j.jaap.2014.05.023

6. Z. Wang, L. Siwei, L. Weigang and S. Wenli, BioResources 10, 4485(2015), DOI: 10.15376/biores. 10.3.4485-4497

7. R. Miandad, M.A. Barakat, M. Rehan, A.S. Aburiazaiza, I.M.I. Ismail, and A.S. Nizami, Waste Management, 69, 66(2017), DOI:10.1016/j.wasman.2017.08.032

8. D. K. Ratnasari, M. A. Nahil, and P. T. Williams, Journal of Analitycal and Applied Pyrolysis, 124, 631(2017), DOI:10.1016/j.jaap.2016.12.027

9. A. West, D. Posarac, and N. Ellis, Bioresource Technology 99, 6587(2008), DOI: 10.1016/j.biortech.2007.11.046

10. H. Juwono, T. Triyono, S. Sutarno, Endang Tri Wahyuni2, H. Harmami1, Ita Ulfin1, Fredy Kurniawan, Bulletin of Chemical Reaction Engineering \& Catalysis, 12, 337(2017), DOI: $10.9767 / \mathrm{bcrec} .12 .3 .811 .337-342$

11. I. Alonso-Lemus, Y. Verde-Gomez, A. Aguilar-Elguézabal, and L. Álvarez-Contreras, Journal of Nanomaterials, 2010, 1(2010), DOI:10.1155/2010/302898

12. H. Juwono, Triyono, Sutarno, E. T. Wahyuni, I. Ulfin, and F. Kurniawan, Indonesian Journal of Chemistry, 17, 316(2017), DOI:10.22146/ijc.24180

13. J. Meng, J. Park, D. Tilotta, and S. Park, Bioresource Technology, 111, 439(2012), DOI: 10.1016/j.biortech.2012.01.159

14. H. Juwono, K. A. Nugroho, R. Alfian, Y. L. Ni'mah, D. Sugiarso, Harmami, Journal of Physics: Conference Series, 1156, 012013 (2019), DOI:10.1088/1742-6596/1156/1/012013

15. E. F. Illiopoulou, E. V. Antonakuo, S. A. Karakoulia, I. A. Vasalos, A. A. Lappas, and K. S. Triantafyllidis, Chemical Engineering Journal, 134, 51(2007), DOI:10.1016/j.cej.2007.03.066

16. Y.A. Aubakirov, L. R. Sassykova, Zh. Kh. Tashmukhambetova, F. Zh. Akhmetova, S. Sendilvelan, K.O. Sharipov, Sh. N. Kubekova, A.A. Batyrbayeva, R.N. Azhigulova, R. G. Ryskaliyeva, A. K. Zhussupova and T. S. Abildin, Rasayan Journal of Chemistry, 12(4), 1701(2019), DOI: $10.31788 /$ RJC.2019.1245435

17. J.L. Sihombing, A.L. Pulungan, M. Zubir, Jasmidi, A.A. Wibowo, S. Gea, B. Wirjosento, and Y.A. Hutapea, Rasayan Journal of Chemistry, 12(1), 205(2019), DOI:10.31788/RJC.2019.1215036

18. D. Li, P. Bui, H. Y. Zhao, S. T. Oyama, T. Dou, and Z. H. Shen, Journal of Catalysis, 290, 1(2012), DOI: $10.1016 / \mathrm{S} 0021-9517(12) 00136-4$

19. E. F. Illiopoulou, E. V. Antonakuo, S. A. Karakoulia, I. A. Vasalos, A. A. Lappas, and K. S. Triantafyllidis, Chemical Engineering Journal, 134, 51(2007), DOI:10.1016/j.cej.2007.03.066

20. O. Sanahuja-Parejo, A. Veses, M. V. Navarro, J. M. Lopez, R. Murillo, M. S. Callen, and T. Garcia, Chemical Engineering Journal, 337, 120246 (2019), DOI:10.1016/j.cej.2018.10.183

21. E. B. Hassan, I. Elsayed, and A. Eseyin, Fuel, 174, 317(2016), DOI:10.1016/j.fuel.2016.02.031

22. M. Yang and Y. Shibasaki, Journal of Polymer Science Part A : Polymer Chemistry, 36(13), 2315(1998), DOI: 10.1002/(SICI)1099-0518(19980930)36:13<2315::AID-POLA19>3.0.CO;2-D

23. O. Sanuhaja-Parejo, A. Veses, M. V. Navarro, J. M. Lopez, R. Murillo, M. S. Callen, and T. Garcia, Catalysts, 9,12(2019), DOI: 10.3390/cata19120992

24. S. Sendilvelan and K. Bhaskar, Rasayan Journal of Chemistry, 10(3), 1043(2017) DOI: $10.7324 /$ RJC.2017.1031703

[RJC-6056/2020] 